\title{
Effect of Copper Foliar Spray upon the Contents of Other Elements in Apple Leaves
}

\author{
Manfred Sager ${ }^{1}$, Andreas Spornberger ${ }^{2}$ \\ ${ }^{1}$ Austrian Agency for Health and Food Safety, Special Investigations in Trace Element Analysis, Spargelfeldstrasse 191, \\ 1220 Wien \\ ${ }^{2}$ University of Natural Resources and Life Sciences Vienna, Department of Crop Sciences, Division of Viticulture and \\ Pomology, Gregor Mendel Strasse 33, 1180 Wien
}

\begin{abstract}
Apple leaves of cultivars Topaz and Golden delicious, organically grown upon spindly shaped apple trees and grafted at 5 dwarfing rootstocks, were analyzed for 42 main and trace elements. Spraying a Cu-oxychloride particle suspension plus an adherent as a fungicide, induced some leaf concentration changes with respect to untreated control groups, though inputs of other elements from spraying were negligible. Cu-treatment tended to increase concentrations of $\mathrm{Fe}$, Si and J, and to decrease Zn, Co and Cd in the leaves, because these effects appeared for both cultivars at all rootstocks. Other changes might be rather due to fertilization regime and climate.
\end{abstract}

Keywords-apple leaves, Cu-spraying, trace elements, year-to-year variation.

\section{INTRODUCTION}

In order to cope with fungal diseases during organic viticulture and fruit farming, use of foliar copper spraying up to 6 $\mathrm{kg} / \mathrm{ha}$.a has been generally permitted within the EU [1]. Fixation of copper-hydroxide or copper-oxychloride particles at leaf surfaces can be achieved by emulsions together with adherents like ethoxylated rapeseed oil or soy oil. Simulation of elution by rain drops showed that adherents decreased $\mathrm{Cu}$-losses from leaves within the first $30 \mathrm{~mm}$ of rain got decreased from 75 $90 \%$ down to $10-25 \%$, and increased the covered surface area per particle. Washout to the soil left the particles rather unchanged [2,3]. Within the soil, the $\mathrm{Cu}$-containing particles get irreversibly adsorbed at humics and pedogenic oxides within a few hours, leaving exchangeable fractions within a few percent of total [4].

Because $\mathrm{Cu}$ is much more toxic towards fungi than towards bacteria, $\mathrm{Cu}$ inputs decreased fungal biomass, whereas bacterial phospholipids and xylanase were not affected, but effects upon the mycorrhiza remained unclear. Thus, effects upon bacterially driven $\mathrm{N}-$, P- and C- cycles seem less pronounced [5].

Though numerous studies about $\mathrm{Cu}$-speciaton and mobilities in soil, as well as toxicity symptoms in green plants are available, effects upon the metabolism of other elements after $\mathrm{Cu}$-spraying are largely unknown.

In green plants, about $98 \%$ of total $\mathrm{Cu}$ is bound to various organic molecules. $\mathrm{Cu}$ shows high affinities to thiol groups of peptides, and thus to proteins rich in cystein. But it may also form stable chelates with carboxylic and hydroxylic groups, often assisted by groups containing basic nitrogen. $\mathrm{Cu}$-containing enzymes catalyse electron transfer reactions, like photosynthesis, respiration, perception of ethylene, metabolism of reactive oxygen, and remodeling of cell walls. Many $\mathrm{Cu}-$ proteins have a functional counterpart that uses $\mathrm{Fe}[6,7]$.

Whereas divalent $\mathrm{Cu}$ shows high affinity to histidine, monovalent $\mathrm{Cu}$ favors cystein or methionine. In case, metals are transported by a common transport protein, $\mathrm{Cu}$ can displace other essential metals in metallo-proteins because of its high stability of its thiol complexes. According to the Irving-Williams-series, the stability of bondings between metallo-proteins and metals increases within $\mathrm{Ca}^{2+}<\mathrm{Mg}^{2+}<\mathrm{Fe}^{2+}<\mathrm{Co}^{2+}<\mathrm{Ni}^{2+}-\mathrm{Cu}^{2+}-\mathrm{Cu}^{+}[7,8]$.

Small organic molecules like mugeinic acid or nicotianamine (N-N-(3-amino-3-carboxypropyl)-3-amino-3-carboxypropyl) azetidine-2-carboxylic acid) are utilized to transport essential metals like $\mathrm{Cu}, \mathrm{Fe}, \mathrm{Mn}, \mathrm{Ni}$ or $\mathrm{Zn}$ within the green plant. In vitro, the complexation capability of nicotianamine increases within the sequence $\mathrm{Mn}-\mathrm{Fe}-\mathrm{Co}-\mathrm{Zn}-\mathrm{Ni}-\mathrm{Cu}$, and peaks at pH 6,5. In case of $\mathrm{Cu}, \mathrm{Fe}$ or $\mathrm{Zn}$ deficiencies, nicotianamide get increasingly formed, but this necessitates, however, high supply of nitrogen [6]. At Cu-deficiency, Cu-treatment induces the formation of metallothioneins, which assist the reconstruction of plasma membranes and act as anti-oxidants [9]. Within the roots, both $\mathrm{Cu}$ and $\mathrm{Fe}$ get reduced by root cell ferric reductase. When given in excess, plants have reduced $\mathrm{Fe}$ uptake, and vice versa [6]. Excess $\mathrm{Cu}$ concentrations tend to decrease root growth because of preferential $\mathrm{Cu}$ - accumulation in that organ. 
In case $\mathrm{Cu}$ is taken from the soil, the most frequent symptom of $\mathrm{Cu}$ - intoxications is chlorosis as well as reduced uptake of $\mathrm{Fe}$. In addition to chlorosis, excess $\mathrm{Cu}$ causes symptoms like necrosis, and reduced growth. Inside the cells, excess $\mathrm{Cu}$ can disrupt protein structures, reduce enzyme activities, interfere in the biosynthesis of photosynthetic pigments and membranes, cause deficiencies of other essential elements, and induce oxidative effects [8]. $\mathrm{Cu}$-induced $\mathrm{Fe}$ deficiency, replacement of $\mathrm{Mg}$ by $\mathrm{Cu}$, or destruction of the oxygen transporting polypeptide decreases chlorophyll content.

Therefore, the $\mathrm{Cu}$ - tissue levels are regulated within a narrow physiological range by homeostasis. Frequently, green plants have specific metal sensors, which start a cascade of signals to induce corresponding reactions. The green plant can protect itself against excess $\mathrm{Cu}$ by stimulation of excretion, increase of chelators, and separation into a vacuole [8].

Immissions of toxic amounts of $\mathrm{Cu}$ can be caused by industrial and residential wastes, pig manure and poultry dung, and also $\mathrm{Cu}$ foliar sprays. Most papers about metal tolerance deal with elevated soil or hydroponic Cu levels. Among green plants, tolerance versus excess $\mathrm{Cu}$ is highly variable. $\mathrm{Cu}$ tolerant plants are mainly excluders, reacting by reduced secretion of root exsudates, and immobilisation inside the root. Excess soil $\mathrm{Cu}$ gets at first enriched within the roots, lowers root growth, promotes root damage and lowers transport processes inside the plant. Transport of excess $\mathrm{Cu}$ from roots to shoots gets prevented by adherence to cell walls, reduced flux across plasma membranes, increased outflow from the cytoplasma as well as intracellular chelation by organic acids, special phytochelatins, and metallo-thioneins [7].

The reverse transport of $\mathrm{Cu}$ from the leaves back to stalks and roots takes place at leaf aging. Increased $\mathrm{N}$-supply delays aging and affects availability and mobility inside the plant by binding more $\mathrm{Cu}$ to amino acids and proteins. $\mathrm{Cu}$ gets hardly redistributed from old leaves to younger ones [6,7].

In case of $\mathrm{Cu}$-deficiency, because of limited mobility from soil, foliar $\mathrm{Cu}$-spray acts much faster and more effectively than additions to the soil. $\mathrm{Cu}$ levels applied as fungicides, however, are 10-100 times higher than usually needed for fertilization in case of deficiencies [7]. A hydrophobic cuticula protects leaves from external damage. Because the cuticula of young leaves is not so strong, effects of foliar spraying are higher in this case. The adherence of sprayed solutions depends on genotypical differences of leaf surface properties, like hairs and smoothness of surface.

A known interlement effect facilitates the decision to spray each element separately, or to use a mixture and thus safe work. The uptake of foliar-sprayed $\mathrm{Cu}, \mathrm{Mn}$, and B into apple leaves was higher in May than in June and September, and elevated levels of $\mathrm{Cu}$ lasted longer than of $\mathrm{Mn}$ and $\mathrm{B}$. In combination with $\mathrm{Mn}$, the leaves adsorbed less $\mathrm{Cu}$ than without [10]. $\mathrm{Cu}$ addition to sandy soil also increased the uptake of $\mathrm{Ba}, \mathrm{Ca}, \mathrm{Sr}$ and $\mathrm{Fe}$ into the leaves of MacIntosh apple seedlings, but decreased $\mathrm{Mn}$ and Mo. Addition of peat to this sandy soil increased soil adsorption, but also decreased $\mathrm{Cu}$ uptake into the seedlings [11].

In order to document differences in root trace element uptake and foliar spray, young nursery-grown apple trees were grown in pot experiment on quartz sand. Spraying increased the $\mathrm{Cu}$ content of the components that were directly exposed, but hardly increased the $\mathrm{Cu}$ content of other tree components, like roots. Differences in plant growth were marginal. The levels of $\mathrm{N}, \mathrm{P}, \mathrm{K}, \mathrm{Ca}, \mathrm{Mg}$ and $\mathrm{Na}$ in the leaves were about the same after sufficient spraying or soil additions of $\mathrm{Cu}, \mathrm{Mn}, \mathrm{Zn}$ and $\mathrm{B}$ [12].

Within a field trial at the experimental orchard Jedlersdorf (Vienna/Austria), run by the University of Natural Resources Vienna, apples of „Topaz“ cultivar have been grafted upon different rootstocks, beneath a lot of other fruit items. Rootstocks M9 with and without „Rubinola“ as interstem, M26, M7 grafted at $25 \mathrm{~cm}$ and at $55 \mathrm{~cm}$, MM111 and Bittenfelder seedlings, were used, trained as spindles. Growth, yields and mean fruit weights have been reported elsewhere [13]. This enabled us to investigate the effect of rootstocks and the year of growth upon the composition of fruits and leaves at the same site and fertilization regime [14]. In 2012, young leaves were sampled in early June, which had got no Cu-treatment, whereas in 2015 and 2016, young leaves from the same trees were sampled after $\mathrm{Cu}$ treatment. At the same site, apple leaves of Golden delicious variety were available with and without $\mathrm{Cu}$ treatment, grown in 2016.

For $\mathrm{Cu}$ treatment, Cuprofor liquid, containing copper oxichloride, was used, diluted at $0,03 \%$ solution (\%v/v).

\section{MATERIAL AND METHODS}

At the experimental orchard Jedlersdorf (Vienna/Austria) in autumn 2008, 5 rows of spindly shaped apple trees were grafted by variety Topaz at dwarfing rootstocks M9, M26, M7 and M111, as well as on seedling (Bitterfelder). At present, Topaz is the most utilized apple cultivar grown by organic farming in Austria. It has favorable storage properties, high vitamin $\mathrm{C}$ 
contents and a balanced acid-sugar proportion, early flowering stage and late harvest [15]. The trees have been organically grown within 5 rows, each containing 4 trees of each kind randomly distributed.

The soil is of calcaric chernozem type, pH7.6 -7.8, containing about $7 \%$ of total $\mathrm{Ca}$, and low mobile $\mathrm{K}$ (in $0,16 \mathrm{M}$ acetic acid 1 to $20: 137 \mathrm{mg} / \mathrm{kg}$ in the upper $25 \mathrm{~cm}$, and $42 \mathrm{mg} / \mathrm{kg}$ below). Fertilization was done by addition of the organic fertilizer "Biofert" (Austria) to supply N at $30 \mathrm{~kg} / \mathrm{ha} . \mathrm{a}$.

At the day of sampling, leaves of each kind were taken separately within each row, wearing gloves, preferably the third leaf off the sprout tops. All 4 trees within one row were sampled all around, to average light and shadow sites. This enabled to compare the uncertainties between data obtained from different rows and rootstocks, respectively. In the evening after sampling, the leaves were rinsed with de-ionized water upon nylon gauze, put into new poly-ethylene bags, submitted to freeze drying, and finely crashed inside the bags in order to avoid further contacts.

All samples were submitted to two different digestion procedures, at least in duplicate. About $0,25 \mathrm{~g}$ sample was digested with $3,8 \mathrm{ml}$ suprapure $\mathrm{HNO}_{3}$ plus $0,1 \mathrm{ml} \mathrm{HF}$ p.a. in closed vessels by microwave heating, and finally made up to $25 \mathrm{ml}$. In addition, about $1 \mathrm{~g}$ sample was digested with $8 \mathrm{ml}$ of a nitric acid - potassium chlorate solution $\left(20 \mathrm{~g} \mathrm{KClO}_{3}\right.$ p.a. $+200 \mathrm{ml}$ $\mathrm{H}_{2} \mathrm{O}+80 \mathrm{ml} \mathrm{HNO}_{3}$ suprapure), and finally made up to $25 \mathrm{ml}$ also [16]. Ultrapure water and polythene volumetric flasks were used throughout.

The resultant digestion solutions were submitted to multi-element analysis by ICP-OES (Perkin-Elmer Optima 3000XL) operating with a horizontally mounted torch, as well as ICP-MS (Perkin Elmer Sciex ELAN DRC II) for selected low level trace elements. $\mathrm{KClO}_{3}$ digestion solutions were analyzed at the ICP-OES versus matrix matched calibrants, others with calibrants containing $\mathrm{K}, \mathrm{Ca}$ and $\mathrm{P}$ within expectable ranges. For ICP-MS measurements, samples were diluted 1+9, indium added as internal standard, and read for the elements $\mathrm{Bi}, \mathrm{Cd}, \mathrm{Co}, \mathrm{Mo}, \mathrm{Ni}, \mathrm{Pb}, \mathrm{Tl}, \mathrm{Y}$ and Rare Earth elements). Total iodine was determined in special runs at higher plasma power than the default, after dilution with 1/80 diluted digestion reagent solution, and standard addition of iodate calibrants.

The $\mathrm{KClO}_{3}$ digest is especially useful for the determination of non-metals $\mathrm{B}, \mathrm{Si}, \mathrm{S}$ and $\mathrm{I}$, because they get partially volatilized from conc. $\mathrm{HNO}_{3}$ [16]. Unexpected purity of the $\mathrm{KClO}_{3}$ permitted the determination of all main and trace elements, except $\mathrm{K}, \mathrm{Rb}$ and $\mathrm{Cs}$.

The fungizide Cuprofor was refluxed with $\mathrm{HNO}_{3}$ or $\mathrm{HCl}$, made up to $100 \mathrm{ml}$, and measured at the ICP after various dilutions and for $\mathrm{Cu}$ by flame-AAS. An oily precipitate was filtered off. $\mathrm{HNO}_{3}$ and $\mathrm{HCl}$ yielded the same results.

Total nitrogen contents of the leaves were obtained by combustion utilizing a LECO FP-528 Nitrogen-Analyzer.

\section{RESULTS AND DISCUSSION}

The $\mathrm{Cu}$-containing fungicide was quite pure with respect to other inorganics, and thus contributed negligible loads of other elements to the leaves. It contained less than $5 \%$ of $\mathrm{Mg}, \mathrm{Ca}, \mathrm{Sr}$ and $\mathrm{Mn}$ concentrations encountered in dry leaves, as well as $\mathrm{Li}, \mathrm{Al}, \mathrm{Fe}, \mathrm{Pb}$ and $\mathrm{Ni}$ in slight excess (Table 1). This could not increase leaf concentrations substantially.

TABLE 1

\section{CONCENTRATIONS FOUND IN CUPROFOR PER WEIGHT}

\begin{tabular}{|c|c|c|c|}
\hline $\mathbf{C u} \mathbf{2 8 . 9} \pm \mathbf{1 . 7} \%$ & $\mathbf{m g} / \mathbf{k g}$ & & $\mathbf{~} \mathbf{g} / \mathbf{k g}$ \\
\hline $\mathbf{N a}$ & $1535 \pm 187$ & $\mathbf{C r}$ & $8.5 \pm 1.1$ \\
\hline $\mathbf{C a}$ & $613 \pm 43$ & $\mathbf{C d}$ & $2.0 \pm 0.5$ \\
\hline $\mathbf{F e}$ & $287 \pm 35$ & $\mathbf{P b}$ & $1.7 \pm 0.5$ \\
\hline $\mathbf{Z n}$ & $198 \pm 20$ & $\mathbf{C o}$ & $1.7 \pm 0.5$ \\
\hline $\mathbf{K}$ & $158 \pm 103$ & $\mathbf{M n}$ & $1.1 \pm 0.4$ \\
\hline $\mathbf{A l}$ & $154 \pm 54$ & $\mathbf{N i}$ & $1.1 \pm 0.4$ \\
\hline $\mathbf{M g}$ & $47 \pm 16$ & $\mathbf{S r}$ & $0.85 \pm 0.15$ \\
\hline & & $\mathbf{L i}$ & $0.32 \pm 0.10$ \\
\hline
\end{tabular}

Whereas in leaves taken in 2012, Cu levels were ambient, $\mathrm{Cu}$ in leaves taken 2015 ranged about $100-150 \mathrm{mg} / \mathrm{kg}$, which would be highly toxic, if the same load had come via the soil, because of irreversible root damage. It exceeds the legal limit of $90 \mathrm{mg} / \mathrm{kg}$, given in the Austrian standard ÖNORM S 2203, entitled "Requirements for manufactured soils from compost" [17]. Leaves sampled in 2016 contained about $50-70 \mathrm{mg} / \mathrm{kg} \mathrm{Cu}$. 
Trends of element concentrations induced by $\mathrm{Cu}$-spraying seem to be real, if the same effects occur upon all rootstocks, as well as within several growing seasons and cultivars.

When concentration ranges met in apple leaves and grown upon various rootstocks, are depicted as boxplots, possible differences get easily visualized, but contrary to Table 2, medians and the within 50\%-ranges are shown. Figs. 1-7 show some boxplots assorted to rootstocks, year and cultivars, for those elements, which yielded equal patterns in subsequent years. These patterns were shifted in parallel with respect to 2012 data to higher values in 2015 and 2016 in case of Fe, Si and I, and to lower values in case of $\mathrm{Cd}, \mathrm{Co}, \mathrm{Zn}$, and possibly Mo and Ti (table 2; figs 1-7). The Rare Earth elements are generally too low to detect such effects. Adverse trends in the two cultivars appeared for $\mathrm{N}, \mathrm{P}$ as well as for $\mathrm{Na}, \mathrm{Sr}, \mathrm{Ni}, \mathrm{Pb}$, and $\mathrm{V}$, if data from leaves grown upon rootstocks M9 are compared (Table 2); they are surely no effect of $\mathrm{Cu}$-spray but of the fertilization regime. Other elements did not show uniform trends and thus do not seem to be affected by $\mathrm{Cu}$ spraying. Also, element proportions like $\mathrm{Ca} / \mathrm{Mg}, \mathrm{Ca} / \mathrm{Mn}$, and $\mathrm{B} / \mathrm{Mo}$ did not show common trends.

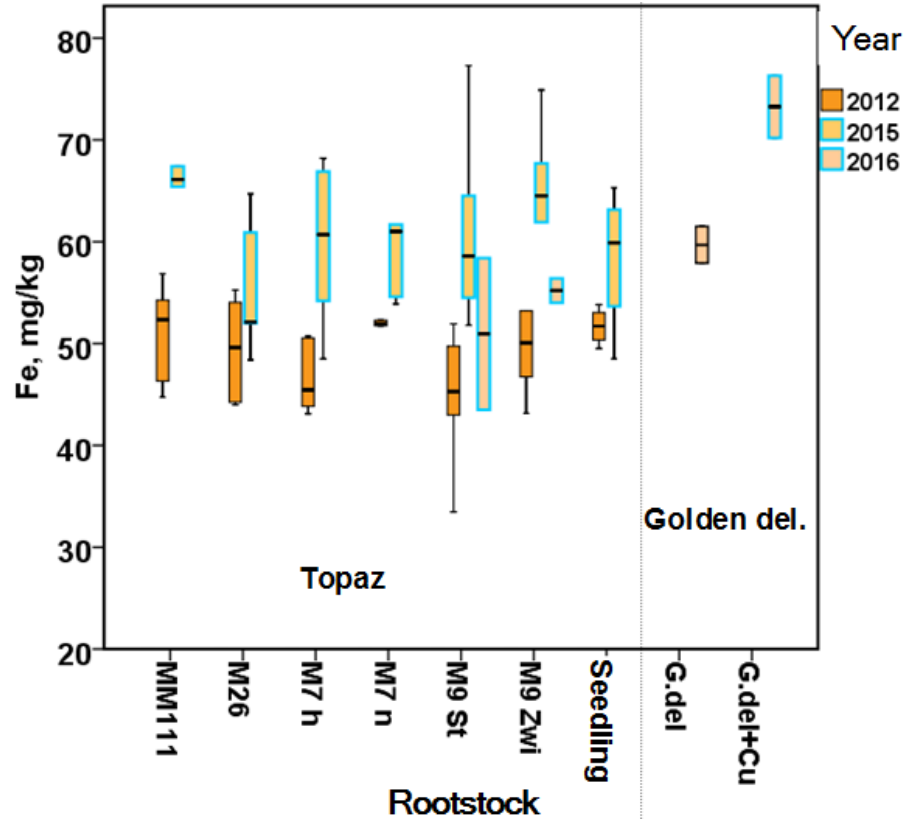

M7 h: M7 grafted at $55 \mathrm{~cm}$ height

M7 n: M7 grafted at $25 \mathrm{~cm}$ height

M9 n: M9 normal

M9 Zwi: M9 grafted with Rubinola as interstem

Seedling: Bittenfelder seedling

Golden delicious grafted at M9

Fig 1. Fe CONTENTS IN APPLE LEAVES!

blue framed boxes: with $\mathrm{Cu}$; black framed boxes: without $\mathrm{Cu}$

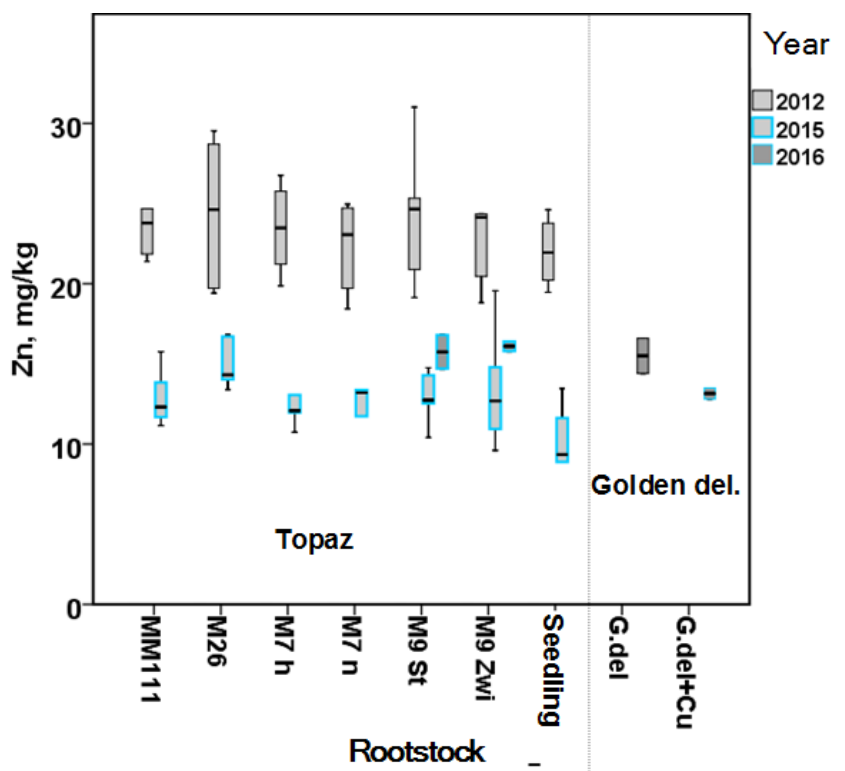

M7 h: M7 grafted at $55 \mathrm{~cm}$ height

M7 n: M7 grafted at $25 \mathrm{~cm}$ height

M9 n: M9 normal

M9 Zwi: M9 grafted with Rubinola as interstem

Seedling: Bittenfelder seedling

Golden delicious grafted at M9

FIG. 2 Zn CONTENTS IN APPLE LEAVES!

blue framed boxes: with $\mathrm{Cu}$; black framed boxes: without $\mathrm{Cu}$ 


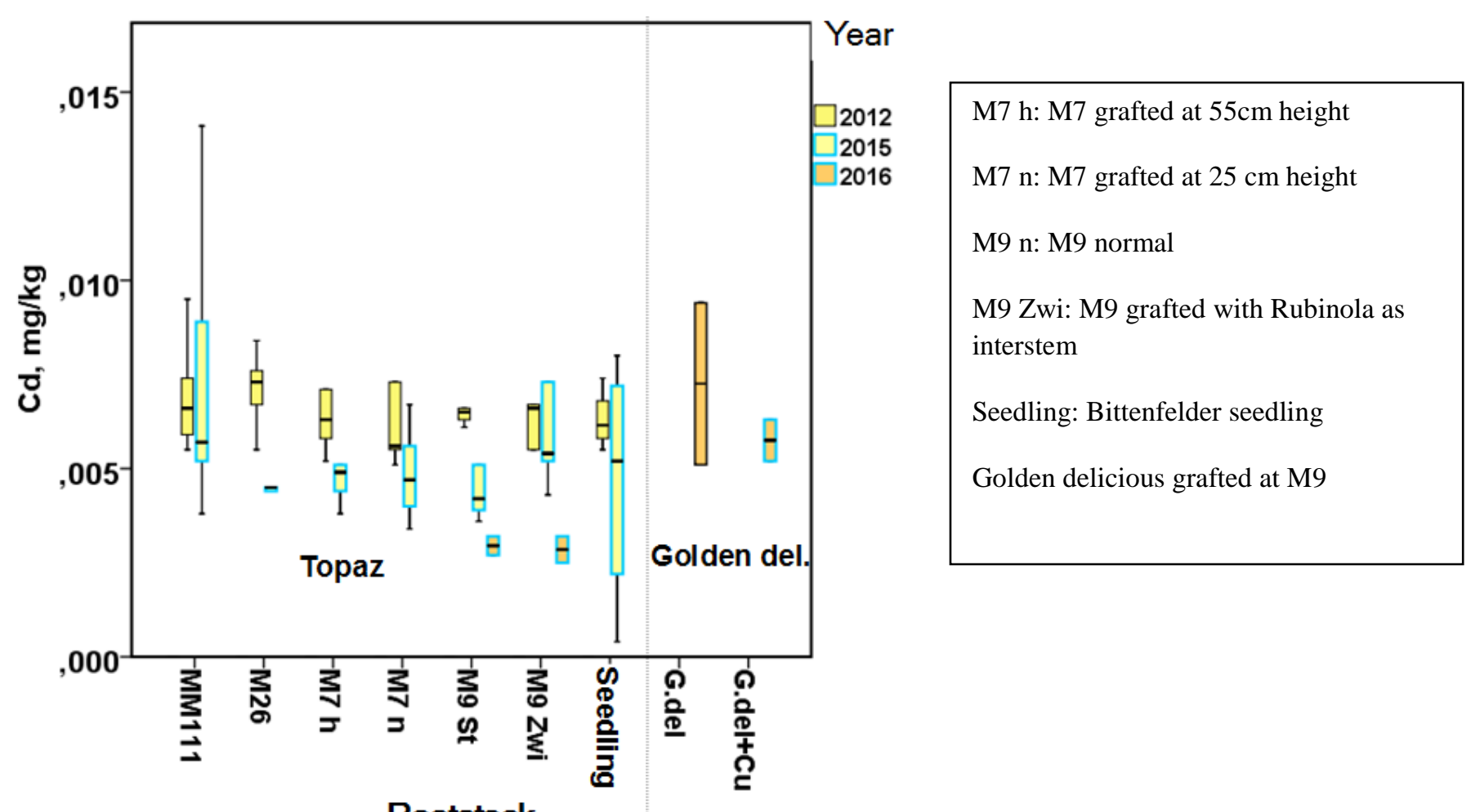

Rootstock

Fig 3. Cd CONTENTS IN APPLE LEAVES!

blue framed boxes: with $\mathrm{Cu}$; black framed boxes: without $\mathrm{Cu}$

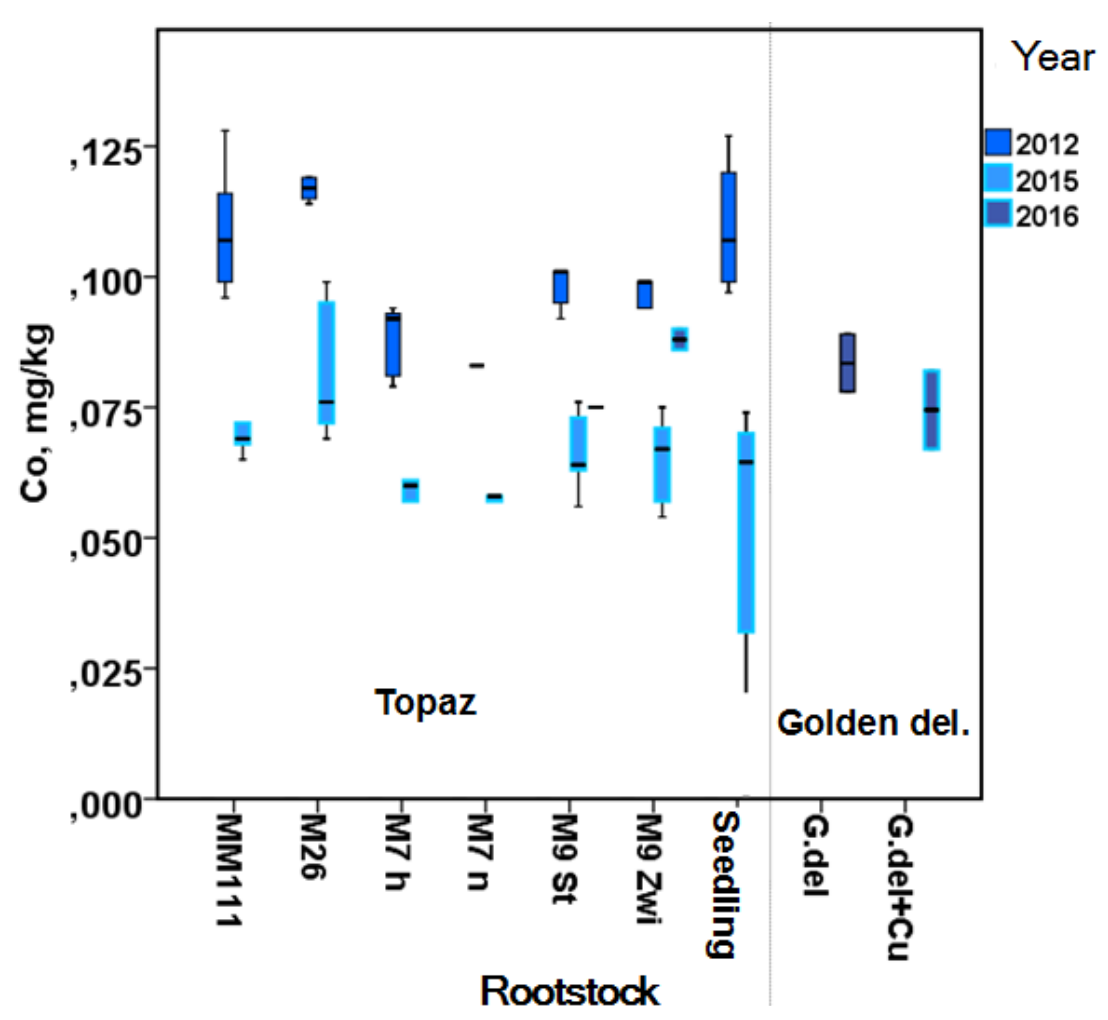

M7 h: M7 grafted at 55cm height

M7 n: M7 grafted at $25 \mathrm{~cm}$ height

M9 n: M9 normal

M9 Zwi: M9 grafted with Rubinola as interstem

Seedling: Bittenfelder seedling

Golden delicious grafted at M9

FIG 4. Co CONTENTS IN APPLE LEAVES

blue framed boxes: with $\mathrm{Cu}$; black framed boxes: without $\mathrm{Cu}$ 


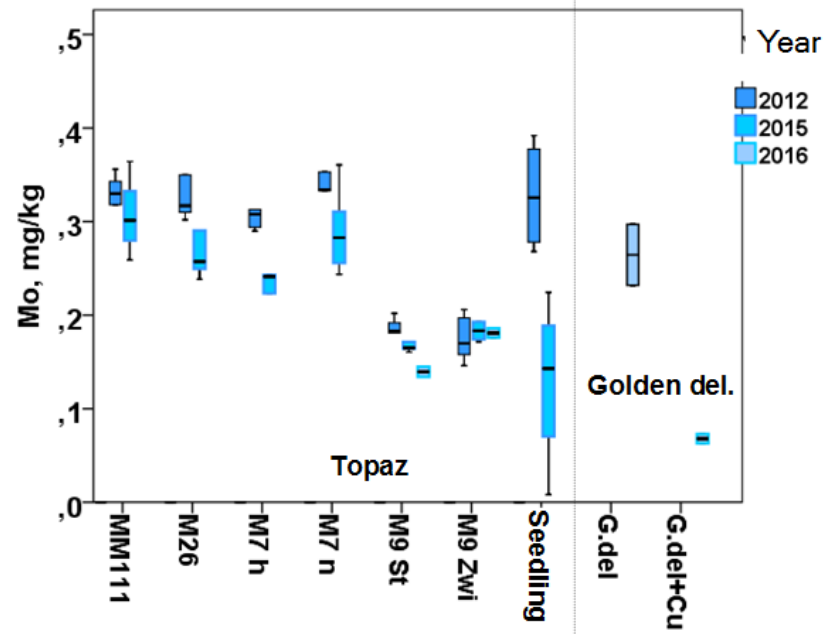

M7 h: M7 grafted at $55 \mathrm{~cm}$ height

M7 n: M7 grafted at $25 \mathrm{~cm}$ height

M9 n: M9 normal

M9 Zwi: M9 grafted with Rubinola as interstem

Seedling: Bittenfelder seedling

Golden delicious grafted at M9

Fig 5. Mo CONTENTS IN APPLE LEAVES

blue framed boxes: with $\mathrm{Cu}$; black framed boxes: without $\mathrm{Cu}$

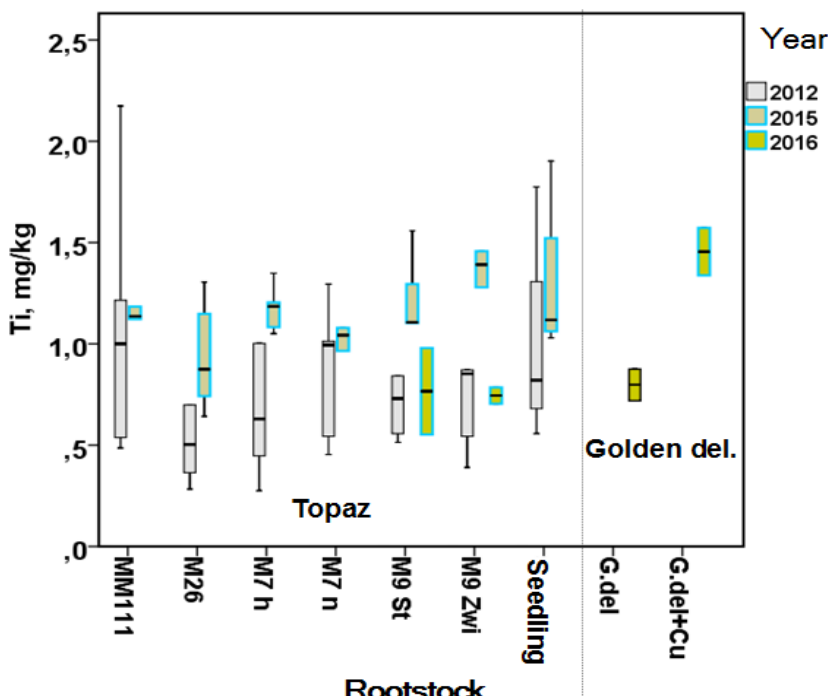

M7 h: M7 grafted at $55 \mathrm{~cm}$ height

M7 n: M7 grafted at $25 \mathrm{~cm}$ height

M9 n: M9 normal

M9 Zwi: M9 grafted with Rubinola as interstem

Seedling: Bittenfelder seedling

Golden delicious grafted at M9

FIG 6. Ti CONTENTS IN APPLE LEAVES

blue framed boxes: with $\mathrm{Cu}$; black framed boxes: without $\mathrm{Cu}$

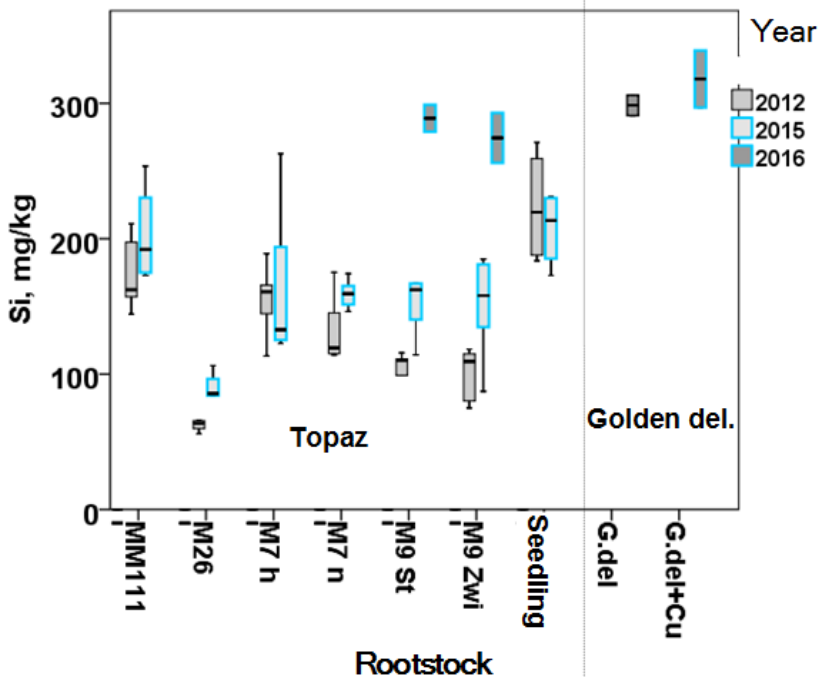

M7 h: M7 grafted at $55 \mathrm{~cm}$ height

M7 n: M7 grafted at $25 \mathrm{~cm}$ height

M9 n: M9 normal

M9 Zwi: M9 grafted with Rubinola as interstem

Seedling: Bittenfelder seedling

Golden delicious grafted at M9

FIG 7. Si CONTENTS IN APPLE LEAVES

blue framed boxes: with $\mathrm{Cu}$; black framed boxes: without $\mathrm{Cu}$ 
TABLE 2

CONCENTRATIONS IN APPLE LEAVES, mg/kg DRY MASS, GRAFTED AT ROOTSTOCK M9 ASSORTED FOR MAIN ELEMENTS, Cu, ESSENTIALS, AND NON-ESSENTIALS

\begin{tabular}{|c|c|c|c|c|c|}
\hline & Topaz 2012 & Topaz 2015 & Topaz 2016 & Golden del. 2016 & Golden del. 2016 \\
\hline$\% \mathrm{~N}$ & $2.82 \pm 0.15$ & $2.65 \pm 0.22$ & $2.19 \pm 0.04$ & $2.37 \pm 0.04$ & $2.50 \pm 0.04$ \\
\hline$\% \mathrm{Ca}$ & $1.313 \pm 0.135$ & $1.331 \pm 0.227$ & $1.974 \pm 0.184$ & $1.673 \pm 0.155$ & $1.529 \pm 0.035$ \\
\hline$\% \mathrm{~K}$ & $0.707 \pm 0.082$ & $0.684 \pm 0.140$ & $1.122 \pm 0.127$ & $1.909 \pm 0.542$ & $1.925 \pm 0.075$ \\
\hline$\% \mathrm{Mg}$ & $0.388 \pm 0.035$ & $0.358 \pm 0.043$ & $0.391 \pm 0.038$ & $0.266 \pm 0.016$ & $0.299 \pm 0.004$ \\
\hline$\% \mathrm{~S}$ & $0.230 \pm 0.037$ & $0.193 \pm 0.008$ & $0.139 \pm 0.012$ & $0.148 \pm 0.003$ & $0.149 \pm 0.010$ \\
\hline$\% \mathbf{P}$ & $0.200 \pm 0.015$ & $0.192 \pm 0.013$ & $0.162 \pm 0.024$ & $0.139 \pm 0.004$ & $0.148 \pm 0.001$ \\
\hline \multicolumn{6}{|l|}{$\mathrm{mg} / \mathrm{kg}$} \\
\hline $\mathrm{Cu}$ & $10.42 \pm 1.16$ & $131.0 \pm 39.2$ & $50.6 \pm 4.5$ & $8.83 \pm 0.35$ & $71.0 \pm 1.1$ \\
\hline $\mathbf{F e}$ & $48.3 \pm 8.5$ & $62.5 \pm 9.3$ & $53.1 \pm 6.6$ & $59.7 \pm 2.5$ & $73.3 \pm 4.3$ \\
\hline Mn & $37.8 \pm 4.1$ & $40.1 \pm 6.7$ & $27.5 \pm 2.0$ & $42.9 \pm 0.3$ & $35.7 \pm 0.4$ \\
\hline Zn & $24.1 \pm 4.6$ & $13.2 \pm 2.9$ & $15.9 \pm 0.9$ & $15.5 \pm 1.6$ & $13.2 \pm 0.5$ \\
\hline B & $27.9 \pm 2.0$ & $23.4 \pm 3.5$ & $26.7 \pm 0.8$ & $30.8 \pm 0.1$ & $30.2 \pm 0.9$ \\
\hline Mo & $0.180 \pm 0.020$ & $0.189 \pm 0.039$ & $0.160 \pm 0.025$ & $0.265 \pm 0.046$ & $0.068 \pm 0.007$ \\
\hline Co & $0.099 \pm 0.009$ & $0.066 \pm 0.008$ & $0.082 \pm 0.008$ & $0.084 \pm 0.008$ & $0.075 \pm 0.011$ \\
\hline $\mathbf{L i}$ & $0.326 \pm 0.064$ & $0.308 \pm 0.049$ & $0.641 \pm 0.029$ & $1.573 \pm 0.170$ & $0.665 \pm 0.025$ \\
\hline $\mathrm{Na}$ & $35.1 \pm 13.4$ & $22.8 \pm 11.8$ & $9.8 \pm 0.7$ & $11.8 \pm 4.2$ & $15.4 \pm 0.3$ \\
\hline $\mathbf{R b}$ & $3.48 \pm 0.45$ & $3.95 \pm 2.46$ & $3.80 \pm 1.06$ & $0.88 \pm 0.29$ & $4.00 \pm 0.49$ \\
\hline Cs & $0.018 \pm 0.003$ & $0.023 \pm 0.007$ & $0.020 \pm 0.001$ & $0.005 \pm 0.001$ & $0.013 \pm 0.003$ \\
\hline $\mathrm{Be}$ & $<0.003$ & $<0.003$ & $<0.003$ & $<0.003$ & $0.004 \pm 0.001$ \\
\hline $\mathbf{S r}$ & $26.0 \pm 4.7$ & $28.0 \pm 5.4$ & $32.3 \pm 2.8$ & $42.6 \pm 13.8$ & $24.6 \pm 0.1$ \\
\hline $\mathbf{B a}$ & $44.5 \pm 7.9$ & $37.9 \pm 7.0$ & $52.8 \pm 2.5$ & $25.7 \pm 1.6$ & $28.6 \pm 0.7$ \\
\hline Al & $32.8 \pm 4.6$ & $32.7 \pm 8.3$ & $68.9 \pm 5.5$ & $61.3 \pm 6.7$ & $84.1 \pm 5.6$ \\
\hline Sc & $<0.05$ & $<0.05$ & $<0.05$ & $<0.05$ & $<0.05$ \\
\hline $\mathbf{Y}$ & $0.014 \pm 0.002$ & $0.017 \pm 0.004$ & $0.015 \pm 0.001$ & $0.015 \pm 0.004$ & $0.029 \pm 0.014$ \\
\hline La & $0.027 \pm 0.011$ & $0.029 \pm 0.007$ & $0.023 \pm 0.003$ & $0.031 \pm 0.003$ & $0.058 \pm 0.015$ \\
\hline $\mathrm{Ce}$ & $0.051 \pm 0.008$ & $0.057 \pm 0.016$ & $0.044 \pm 0.005$ & $0.061 \pm 0.000$ & $0.121 \pm 0.023$ \\
\hline Pr & $0.006 \pm 0.002$ & $0.007 \pm 0.002$ & $0.005 \pm 0.001$ & $0.006 \pm 0.001$ & $0.013 \pm 0.003$ \\
\hline Nd & $0.021 \pm 0.009$ & $0.026 \pm 0.007$ & $0.019 \pm 0.002$ & $0.025 \pm 0.002$ & $0.050 \pm 0.014$ \\
\hline Sm & $0.004 \pm 0.002$ & $0.005 \pm 0.001$ & $0.004 \pm 0.001$ & $0.004 \pm 0.001$ & $0.009 \pm 0.003$ \\
\hline $\mathbf{E u}$ & $0.010 \pm 0.001$ & $0.007 \pm 0.002$ & $0.011 \pm 0.001$ & $0.007 \pm 0.003$ & $0.007 \pm 0.001$ \\
\hline Gd & $0.004 \pm 0.001$ & $0.004 \pm 0.001$ & $0.004 \pm 0.001$ & $0.004 \pm 0.0001$ & $0.008 \pm 0.003$ \\
\hline $\mathbf{T b}$ & $<0.001$ & $<0.001$ & $<0.001$ & $<0.001$ & $<0.001$ \\
\hline Ho & $<0.001$ & $<0.001$ & $<0.001$ & $<0.001$ & $<0.001$ \\
\hline $\mathbf{E r}$ & $0.0015 \pm 0.0003$ & $0.0018 \pm 0.0004$ & $0.0013 \pm 0.0005$ & $0.0010 \pm 0.0000$ & $0.0070 \pm 0.0071$ \\
\hline $\mathbf{L u}$ & $<0.0005$ & $<0.0005$ & $<0.0005$ & $<0.0005$ & $<0.0005$ \\
\hline $\mathbf{T i}$ & $0.89 \pm 0.54$ & $1.27 \pm 0.48$ & $0.76 \pm 0.18$ & $0.80 \pm 0.11$ & $1.46 \pm 0.16$ \\
\hline $\mathbf{V}$ & $0.052 \pm 0.014$ & $0.031 \pm 0.028$ & $0.031 \pm 0.008$ & $0.037 \pm 0.006$ & $0.078 \pm 0.025$ \\
\hline $\mathrm{Cr}$ & $0.065 \pm 0.041$ & $0.174 \pm 0.082$ & $0.056 \pm 0.014$ & $0.058 \pm 0.022$ & $0.099 \pm 0.003$ \\
\hline $\mathbf{N i}$ & $0.29 \pm 0.07$ & $1.63 \pm 0.27$ & $0.69 \pm 0.09$ & $2.12 \pm 0.18$ & $0.92 \pm 0.01$ \\
\hline Cd & $0.0064 \pm 0.0014$ & $0.052 \pm 0.0016$ & $0.0029 \pm 0.0004$ & $0.0073 \pm 0.0030$ & $0.0058 \pm 0.0008$ \\
\hline $\mathbf{S i}$ & $101 \pm 18$ & $156 \pm 40$ & $282 \pm 19$ & $299 \pm 11$ & $318 \pm 30$ \\
\hline $\mathbf{P b}$ & $0.18 \pm 0.02$ & $0.24 \pm 0.03$ & $0.26 \pm 0.02$ & $0.24 \pm 0.05$ & $0.22 \pm 0.06$ \\
\hline $\mathbf{J}$ & $0.263 \pm 0.087$ & $0.487 \pm 0.094$ & $0.421 \pm 0.057$ & $0.317 \pm 0.001$ & $0.400 \pm 0.022$ \\
\hline
\end{tabular}




\section{CONCLUSION}

$\mathrm{Cu}$ - spraying as a fungicide increased $\mathrm{Cu}$ contents in apple leaves to levels, which would be toxic, if this load would have passed through the roots. Though the input of other elements to the leaves was negligible, $\mathrm{Cu}$-spraying might influence the contents of other trace elements in the leaves, like Fe, Si, I, Cd, Co and $\mathrm{Zn}$. This pilot study has to be confirmed by sampling of treated and untreated leaves for the same cultivars at the same sites within the same years. Future results would be interesting for other fruits and vine as well.

\section{REFERENCES}

[1] Commission Regulation (EC) No 473/2002 of 15 March 2002 amending Annexes I, II and VI to Council Regulation (EEC) No 2092/91 „on organic production of agricultural products and indications referring thereto on agricultural products and foodstuffs, and laying down detailed rules as regards the transmission of information on the use of copper compounds“

[2] M. Hunsche, A. Alexeenko, L. Damerow, and G. Noga, Rain -induced removal of copper from apple leaves: influence of rain properties and tank-mix adjuvants on deposit characteristics at the micro scale, Crop Prot. 30, 495-501, 2011

[3] P. Pérez-Rodriguez, D. Soto-Gómez, J.E. López-Periago, and M. Paradelo, „Modeling raindrop strike performance on copper washoff from vine leaves“, J. Environ. Management 150, 472-478, 2015

[4] M. Arias, E. Lopéz, D. Fernández, and B. Soto, „Copper distribution and dynamics in acid vineyard soils treated with Cu-based fungicides“, Soil Science 169 (11), 796-805, 2004

[5] K.A. Mackie, T. Müller, S. Zikeli, and E. Kandeler, „Long-term copper application in an organic vineyard modifies spatial distribution of soil micro-organisms", Soil Biol. Biochem. 65, 245-253, 2013

[6] J.L. Burkhead, K.A.G. Reynolds, A.E. Abdel-Ghany, C.M. Cohu, and M. Pilon, „Copper homeostasis“. New Phytologist 182, 799816, 2009.

[7] H. Marschner, 2012 "Mineral Nutrition of Higher" Plants, 3rd ed. (P. Marschner ed.) Academic Press London 2012.

[8] I. Yruela, "Copper in plants: acquisition, transport and interactions", Functional Plant Biology 36, 409-430, 2009.

[9] J.M. Merillon, and K.G. Ramawat (eds.), "Plant Defence: Biological Control", in: Progress in Biological Control 12, DOI 10.1007/978-94-007-1933-0_5, ( ) Springer Science+Business Media B.V. 2011.

[10] L. Naseri, K. Arzani, M. Babalar, "Foliar B, Cu and Mn uptakes and concentrations of apple leaves c.v. Golden delicious on M9 and B9 rootstocks", Acta horticulturae 594, 237-243, 2002

[11] J. Wooldridge, "Effect of trace element sprays and fritted trace elements on the growth and $\mathrm{Mn}, \mathrm{Zn}, \mathrm{Cu}$, and $\mathrm{B}$ contents of young Braestar/M793 apple trees in sand culture", J. Plant Nutr. 25(1), 43-59, 2002.

[12] A. Spornberger, E. Schüller, E. Videki, and G. Vegvari, „Influence of rootstocks on the performance of the apple cultivatr „Topaz“ according to organic production conditions in Eastern Austria“, Proc. of the ALVA meeting 2017 at Wesenufer/Upper Austria, pp. 268-270; ISSN 1606-612X

[13] M. Sager, and A. Spornberger, „Gehalte an Haupt- und Spurenelemente in Früchten und Blättern von Äpfeln in Abhängigkeit verschiedener Unterlagen“, Mitteilungen Klosterneuburg 65, 250-272, 2015

[14] F. Ruess, „Resistente Apfelsorten“, Obst und Garten (1): 14-57, 2012

[15] M. Sager, "Microwave- assisted digestion of organic materials with $\mathrm{KClO}_{3} / \mathrm{HNO}_{3}$ for the analysis of trace metals and non-metals", Analytical Chemistry- an Indian Journal 10 (2), 101-108, 2011

[16] Austrian standard ÖNORM S 2203: „Requirements for manufactured soils from compost“ (Anforderungen an Kulturerden aus Kompost), issued Aug. $1^{\text {st }}, 2004$ 